\title{
ENVIRONMENTAL POLLUTION - PARASITIC POLLUTION
}

\section{Dumitru Erhan}

Institute of Zoology, Chişinău, Republic of Moldova , e-mail: dumitruerhan@yahoo.com

\begin{abstract}
The paper presents the danger caused by environmental pollution (water, soil, vegetables, fruits, animal and plant products) with parasitic elements eliminated and spread by humans and animals, as well as the importance of conducting research in this field. An important role is also played by the high level of infestation, with various parasitic agents, of animals in the Republic of Moldova. Mention is made of the huge volume of invasive forms eliminated by infested animals.
\end{abstract}

\section{Introduction}

The ecological aspects of zooparasitology began to develop intensively in the first half of the twentieth century $[44,50,51,54]$. The term "ecological parasitology" was introduced and gradually this direction became dominant $[5,26,38,46]$. Parasitology is an integral part of ecology, as the science of the relationships of organisms with each other and the environment. Some ecologists have long underestimated the importance of the concepts and data of parasitology. A turning point occurred at the end of the twentieth century, when, together with the greening of parasitology, the parasitologizing of ecology is observed [41].

The subject of ecological parasitology are parasites, their hosts and the environment with the full diversity of their interactions. These components form parasitic systems with varying degrees of complexity, outside of which the existence of parasites is impossible. The most significant contribution to the development of the concept of parasitic systems was made by Beklemishev [39, 40].

He wrote that "the parasitic system consists of the population of parasites, along with all the populations of the host, which directly support its existence." By the parasitic system, he meant the population of various parasitic agents, along with all the species populations of its hosts, which directly support its existence.

The problems of ecological parasitology are widely and efficiently addressed in many countries. Parasitism, as one of the life forms, is a general biological phenomenon and is characteristic of many taxa of living organisms, from viruses to multicellular animals and plants, although the understanding of the essence of this phenomenon is not yet unambiguous. To date, there is no clarity about the object of parasitology as a science and the validity of its division into independent disciplines through research objects and methods [2, 3, 23, 25, 26, 27] (Fig. 1).

Pollution of the environment - of water, soil, air, vegetables, fruit, products of animal and plant origin and others - with parasites removed and disseminated by humans and animals, constitute a permanent, mass danger of exposure to infestation and thereby willingly entering the biological cycles of the huge number of parasite species.

It is enough to emphasize the danger of pollution with enormous amounts of invasive elements, in children's playgrounds by cats and, especially, by stray dogs, highly parasitized, or inside cattle farms, a huge number of invasive elements eliminated by caring people, infested 
with Taenia saginata and others. [25, 30].

The World Health Organization (WHO) indicates that 4.3 billion people are infected with various parasitic agents, over 16 million deaths per year, or about a third of all cases, are caused by infectious and parasitic diseases (helminthic): nematode, trematode, cestode [37].

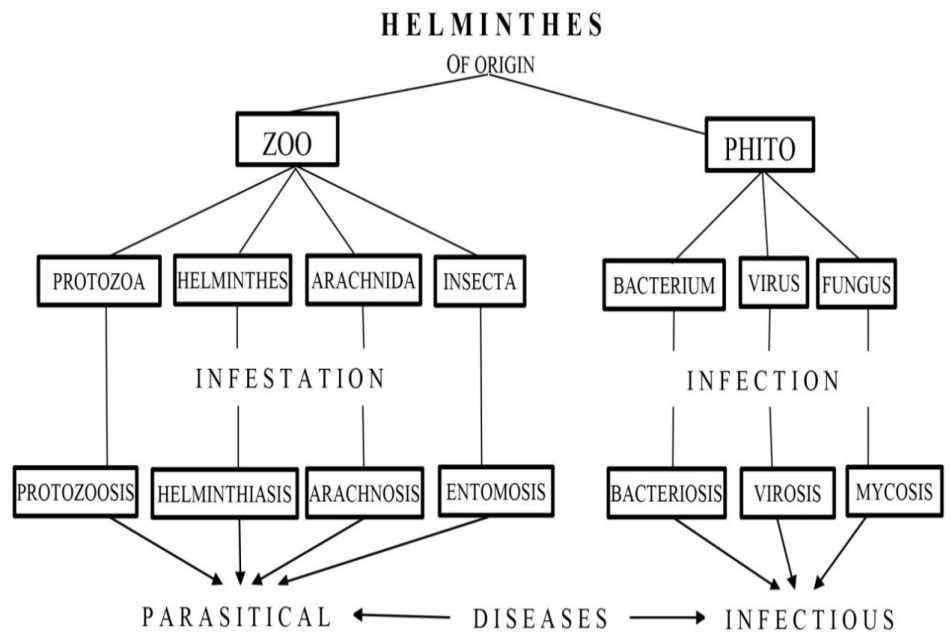

Fig. 1. Diversity of parasites according to origin and diseases caused by them (after [25])

Of great importance is the pollution of vegetables, etc. by infesting them with parasite eggs, it reached the lands in question by fertilizing it with manure from parasitized animals. To this is added the massive pollution with parasitic elements from dogs, cats, people, etc.

Data on water infestation with Cryptosporidium and Giardia cysts pose a danger to humans. The percentage of positive soil samples for the presence of cryptosporidae oocysts is different: in the grazing areas it is $22.3 \pm 1.2 \%$, in the bodies on the water surface it is $18.8 \pm 1.1 \%$, and in the wildlife habitats $-13.7 \pm 1.1 \%[1,4,28,43,45]$.

\section{Materials and methods}

Investigations, regarding the determination of parasite species from various animal species, or conducted in the laboratory of Parasitology and Helminthology of the Institute of Zoology. Biological samples were collected from animals from various natural and anthropogenic biocenoses of the Republic of Moldova.

Coproovoscopic (Fulleborn, Darling), coprolarvoscopic (Popov, Baermann) methods, special examination in sarcocystosis according to the Lubyanetsky [48] method, partial parasitological investigations [after 53] and successive washing were used to achieve the proposed objectives.

\section{Results and discussion}

According to scientists, environmental protection is a priority of socio-economic development. In the late 1960s, all industrialized countries adopted laws and administrative measures to protect the ecosystem. Therefore, environmental protection issues become state work pro- 
grams, along with economic and social aspects.

In response to the suggestions of the international commissions, on 31.07 .87 , during the session of the Supreme Soviet of the MSSR, a complex long-term program on the issue of environmental protection and rational use of the resources of the Moldovan Soviet Socialist Republic was approved, lasting until 2005. It is well known that the issue of the environment and resources is international in nature.

In recent years, new data have accumulated on the results of research in the field of parasitology. Some of them determine the trend of the research perspective in this field. A synthesis of these data and theoretical hypotheses can be made on a modern basis. This is the ecological basis of the requirements, taking into account the economic feasibility of the practical application of the technological methods developed.

Despite the fact that the definitions of a phenomenon such as "environmental pollution" given by different scientists may vary, almost all agree on the main point: "Pollution" is understood to mean any adverse change in the environment for living organisms caused by human destructive action on it. Environmental pollution is caused by various factors. This is largely due to a variety of industrial, agricultural and household waste. This includes types of pollution: Chemical, organic, physical, radionuclide and other types of pollution.

However, for many years, the main attention has been paid to technogenic pollution factors and to a much lesser extent to natural factors, ie biological pollution, which consists in changing the properties of the environment due to the increasing number of various types of microorganisms, plants and animals, initiated by anthropopressure.

In this context, it is quite clear that one of the forms of biological pollution (its basic component) is "parasitic pollution". It is not necessary to demonstrate the enormous role that parasitic organisms play in the biosphere. In nature, there are practically no organisms that are not infected with parasites. Humans, animals and plants are populated with a diversity of parasites, which possess various ecological and informational connections with the environment, forming complex parasitic systems [14].

As mentioned by academician Konstantin Skriabin [52], these systems formed during the evolution of the biosphere, uniting various components of biocenoses into independent complexes. Such complexes occur either in the "systemic inorganic" stage (according tо Обухов's terminology, 1989) [49], when rigid and predominantly unilateral connections are observed between components fi is "systemically organic", when fi each of the components is not able to exist independently (outside the system).

One of the most difficult examples of complexes is parasitic systems. Parasitic systems are self-regulating structures, characterized by certain vectors and their rate of change, depending on environmental factors. Often, the changes observed in the number of members of the parasitic systems, caused by the actions of the self-regulating mechanisms, do not lead to the destruction of the systems themselves. Any parasitologist may give examples where the annual dynamics of host infestations with one or other parasite agent fluctuate strongly and yet the multi-annual results show that the state is fairly constant. This is how parasitic systems behave, 
which are not subjected (or are less subject to) to the influence of anthropogenic pressure.

Environmental pollution with parasitic elements is permanent, throughout the time when humans and infested animals eliminate in nature eggs, larvae, proglottids of parasites or even adult parasites. The dimensions of this phenomenon are almost incomprehensible in a short period of time. The issue of the phenomenon is part of the coordinates of ecological parasitology.

Most parasitologists, who have studied the etiological agents of various parasitosis, have also addressed issues related to their relationship with the environment. In the years 19631964, the participants in the works of Complex Parasitological Expeditions (CPE) in Romania paid special attention to the study of the phenomenon of polyparasitic pollution of the environment. For this purpose, 10 complex parasitological expeditions were made. The results obtained showed that the environment is strongly polyparasitic in all its components. It is worth mentioning the intense polyparasitic pollution of manure, livestock farms, feed depots populated by dogs, cats, mice, rats, etc., animal shelters, grazing areas, places for watering animals, means of transport etc. [24, 25].

A similar situation existed in the Republic of Moldova. Until the 90s of the last century in the republic there were 19 pig breeding complexes of 54 thousand heads each, 38 complexes - of 12-24 thousand each, 12 complexes - of 9-11 thousand each, 22 complexes pigs of 7-9 thousand heads each. In the republic there were 3 milk-cargo complexes (with over 1000 milking cows), 26 reed breeding complexes, 31 bull fattening complexes, in 837 households in the republic there were milk-cargo farms. In 1990 alone, there were about 3.430.000 pigs in the republic, about 477.630 head of cattle and about 1.243.000 sheep/goats [47].

The results of our research showed that cattle in households with various maintenance technologies, ages and geographical areas of the Republic of Moldova are infested with echinococci in 13.4-83.3\% of cases, fascioles - 16.9-59.5\%, dicroceles - 23.5-63.5\%, strongyloids 20.0-47.5\%, eimers - 54.4-94.4\% (2-6 months), sarcocysts - 81.2-97.6\% and cryptosporids - in 20.0-34.5\% (calves up to 2 months) of cases [14].

Rusu Stefan et al. [30] mention that canine youth in urban and rural areas in Chisinau were infested with Echinococcus granulolosus - in 3.3-6.3\% of cases, Dipilidium caninum - 5.518.5\%, Toxocara canis - 9 , 6-12.6\%, Toxascara leonine - 40.9-64.9\%, Ancylostoma caninum - 5.4-9.4\%, Trichocehpalus vulpis - 5.5-6.2\% and Eimeria canis in 30.9 -35.9 cases, and adult stray dogs were infested with Echinococcus granulolosus in 14.3-42.7\% of cases, Dipilidium caninum - 25.5-47.3\%, Toxocara canis - 39.6-52.8 \%, Toxascara leonina - 1.9-12.4\%, Ancylostoma caninum - 7.4-16.2\%, Trichocehpalus vulpis - 10.5-24.6\% and with Eimeria canis - in $2.9-4.2 \%$ of cases.

The grazing of animals of various species and ages and limited lands is the most used system in the Republic of Moldova. Based on the concrete epizootological data, it is possible to establish the level of environmental contamination, as well as the impact of deforestation on it. Therefore, overpollution of pastures with animals of different ages and species, as well as their uncoordinated deforestation, is an important factor that can contribute to increasing the extent and intensity of animals with various parasitic agents. 
It has been established that each species of Eimeria is genetically programmed for a number of merogonic generations. It is estimated that around 92,000,000 merozoids can result from a single oocyst. The dynamics of the elimination of oocysts express an increasing intensity in calves up to 6 months and then decreases to higher ages [10]. In lambs and kids suffering from eimeriosis, the level of co-elimination reaches from 1000-2000 to over 100,000 eggs per gram (OPG) [12, 31].

Coprological eliminationsof oocysts in piglets with symptoms of eimeriosis reach over 50.000 OPGs [18].

In apparently healthy rabbits of eimeriosis, oocyst co-elimination is $0.1 \times 1.9 \times 106$ OPG. Oocysts survive up to 150 days in bedding and shady areas. In foals, the co-elimination period of eimeria oocysts is 30-35 days, and the amount reaches from 25 to about 1,100 fecal OPG, and the amount of pollution with eimeria oocysts in cats exceeds 106 OPG $[32,33]$.

Krull (1941) demonstrated that from a single miracle of Fasciola hepatica, which enters a snail - Lymnaea truncatula (intermediate host), about 4000 searches can occur, which turn into metacercises - the invasive form. Dicrocoelium eggs remain viable after 6 months in the faecal masses of pastures and from an egg ingested by terrestrial gastropods, the first intermediate host, then the search finds the second intermediate host - ants, where up to 400.000 metacercariae can appear - form infesting $[11,32]$.

It has been established that the expanding Moniezia expansa, at its maturity, can eliminate up to 100 eggs full of eggs and up to 1.000 .000 eggs per day, respectively. It is known that Moniezia expansa lives in the intestine of the host up to 11 weeks, so the infested animal can spread on the pasture a huge number of parasitic elements (oncospheres) that can take the intermediate host (pasture mites - Oribatidae, Galumnidae) [10]. Taenia cestodes lay 2-3 ovary proglottids containing 100.000 eggs/proglott daily [16, 29], and Echinococcus granulosus oviplot proglottids contain about 1500 eggs [35].

Egg proglottids, after elimination into the outdoor environment, may leave the feces and move more than $25 \mathrm{~cm}$ (Echinococcus granulosus) or up to $90 \mathrm{~cm}$ (Taenia hydatigene), which contributes to the dispersion of eggs in the outdoor environment. The eggs of teniid may be spread over a distance of at least 175 meters by infected dogs and it is estimated that a single dog can polite eggs of at least 30.000 hectares [21].

Insects, birds, and wildlife contribute to the dispersal of eggs over very large areas, sometimes more than $60 \mathrm{~km}[21,36]$.

Dogs experimentally infected with Echinococcus granulosus lay eggs up to 22 months [36]. Difilobotriosis is caused by the cestode Diphyllobothrium latum which measures up to $25 \mathrm{~m}$ in length and can contain 4000 proglottids. Infected humans and/or animals can lay between 2 and 40 million eggs/day [22].

Taenia saginata has a length of 4-10 meters, with 1000-2000 proglottids. The proglott contains from 97.000 to 124.000 eggs, and the annual production of an adult basket is 594.000.000 eggs. The proglottids are evacuated intermittently, up to 12 per day.

Taenia solium produces about 50,000 eggs in each proglott. Cestoda Taenia solium is 3 to 7 
m long. The strobila contains 700-1000 proglottids, and the ovigere ones contain about 50.000 eggs. The parasite grows at a rate of $7 \mathrm{~cm}$ per day, reaching maturity in two months. Adult proglottids, full of eggs, are eliminated with the feces in groups of 3-5 specimens each [10].

Animals infested with nematodes from the family Trichostrongylidae can lay a big number of eggs daily (about 10.000). Biothermically sterilized and spread on pasture manure is an important source of contamination [8].

Carnivores infected with the nematode Ancylostoma caninum pose a danger to the external environment. A female lays 10.000-20.000 eggs/day [7].

A horse infected with strongyls can remove 40x106 eggs/day [34]. Egg removal takes place throughout the year, but there is a seasonal fluctuation - in winter the smallest number of eggs is eliminated [13].

Ascaris suum larvae lay 200.000-1.000.000 eggs daily, leading to massive environmental contamination. In addition, a role in the spread of eggs can be played by paratenic hosts, first of all earthworms [6].

Females of Oxiuris equvi lay up to 60.000 eggs [17]. The females of Parascaris equorum have a very high progeny, being able to eliminate, when they parasitize the foals, up to 1.000.000 eggs/day. The eggs are very hardy, surviving over a year in the outdoor environment. The female Toxocara canis, the dog's nematode, can lay up to 200.000 eggs/day. Due to the thick shell, Toxocara canis embryonated eggs are very resistant to unfavorable factors. Under natural conditions, they remain viable for years [15].

It is known that the main source of parasite for humans is the soil, however more recently it is established that a potential source can fi and dog hair [19].

A female of Ascaridia galli lays up to 170.000 eggs. The source of environmental contamination with parasites are sick and carrier birds. Wild birds can be a reservoir of infestation for domestic birds [33].Prof. Olteanu Gh. [25] asks the question if someone regularly controls whether or not there are parasitic elements on the sands of the beaches on the coast, in the swimming pools and in general in the external environment in Romania? The same situation is in the Republic of Moldova. If the results of such periodic inspections were made known, we would be horrified. Beaches, playgrounds for children, land near animal husbandry, etc. they are "honored" by periodic wanderings of packs of stray and semi-stray dogs, which seem to perpetuate their presence and tendency to grow in number and aggression in all respects. The parasitic load of each of the components of the dog packs is enormous and regenerates in the permanent circuit with the parasitic elements from the environment strongly aggressed by the polyparasitic pollution that it ensures and maintains aggravating it. Polyparasitic pollution of the environment by wild animals, stray dog packs, as well as by other categories of dogs, including those belonging to the canine elite, have a standard of living well above the level of many ordinary people, through access to living conditions in apartments, beds, kitchens, living rooms, balconies, hallways, luxury cars, etc., is a danger of exceptional gravity for the human population. The problem of vectors (insects, ticks, rodents and other animals) of pathogens of diseases caused by protozoa, helminths, bacteria, viruses is far from fi solved, as well as the 
interruption of the transmission chain of pathogens, taking into account the cycles and characteristics of development itself of vectors. The vector-host-pathogen system acts constantly with the species for different species of parasites and conditions. The ability to efficiently suppress the vector population, for a long period of time, is considered decisive in choosing the optimal strategy for combating vector-borne diseases [20].

The difficulty in solving the problem of parasitosis consists in the diversity of parasite species, the high resistance of pathogens to environmental factors, as well as in the existence of the large range of intermediate, complementary hosts in a constantly changing environment.

The problem of parasitic zoonoses, and especially zooanthroponoses, is relevant to the whole world. The transmission of pathogens through the elements of the natural environment and mainly through animal metabolites is dominant in epidemic situations. In this case, the effects of infecting people with parasitic agents from animals are often tragic.

Some theoretical and applied aspects of the parasitosis problem are the following:

- first, in the strategy to control parasites, a constant negative point is observed - the "treatment" of the consequences, without eliminating the cause;

with the poor sanitation of pathogens and the insufficient use of drugs, it is necessary to constantly take into account the emergence of new generations of resistant parasites and their spread in the environment.

In recent years, there is a trend in parasitology, in terms of the ecological nature of processes and technologies. Of particular importance is the ability of parasites, from the stages of the biological cycle, to adapt to complex environmental conditions. It is observed that they can survive in extreme conditions during adaptation, expansion of the host spectrum and even in the shortening of biological cycles [20].

The high degree of adaptation of helminths and protozoa and counteracting the body's protective forces is explained by the fact that parasites in the molecular structure of their proteins, reproduce the structure of a number of host immunoregulatory proteins and suppress their immunity. At the same time, they survive and develop successfully.

Ecological prevention of parasitic diseases is based on the results of basic research in different directions. These directions in parasitology are important in general biology, veterinary medicine, human medicine and agronomy. In contemporary veterinary parasitology, the ecological direction of research is becoming increasingly important in the case of restructuring animal husbandry technologies. Ecological aspects refer, first of all, to pathogenic parasitic agents, whose biological development cycles are closely related to the environment. For this reason, it can fi formulate the following scientific direction fi that research - the bioecology of pathogens, the basic elements and biotechnological principles of environmental protection from pathogens.

This problem is multifactorial. In this context, ongoing epizootic monitoring and complex research are needed. Based on the results obtained, it is necessary to develop modern regulatory documents and standards, respecting the rules of ecological safety of objects in the veterinary complex. 
In the strategy to combat parasitosis, this direction, in terms of science and application, requires independent development. Global environmental pollution, associated with anthropogenic pressure, requires the development of integrated control methods. We emphasize in particular the fact that, in the last years, there is an obvious orientation of the promotion of ecological parasitology both in general, theoretical, and in applicative, medical plan.

The studies were carried out within the research project no. 20.80009.7007.12.

\section{Bibliography}

1. Balaban N., Tezeren D., Zturk S. Cryptosporidium. Turk Hijyen ve Deneysel Biyoloji Dergisi. 1995, Vol. 52. №2. - P. 99-102.

2. Brooks D.R., McLennan D.A. Parascript: Parasites and the language of evolution. Washington, 1993. - $420 \mathrm{p}$.

3. Bush A.O., Fernandez J., Esch G.W., Seed J.R. Parasitism. The diversity and ecology of animal parasites. Cambridge Univ. Press, 2002. - 566 p.

4. Cicirello H.G., Kehl K.S., Addiss D.G. et.al. Cryptosporidiosis in chil- dren during a massive waterborne outbreak in Milwaukee, Wisconsin: Clinical, Laboratory and Epidemiologic Findings //Epidemiology and Infections. 1997, Vol. 119. №1. - P. 53-60.

5. Croll N.A. Ecology of parasites. Cambridge. Harvard Univ. Press, 1966. - 136 p.

6. Dărăbuș Gh., Cosoroabă I., Druga M. Inactivarea unor elemente parazi- tare din dijecțiile de porc sub influența fermentației metanice termofile. Lucr. Șt. Med. Vet., Timișoara. 1991, XXV. - P. 65-68.

7. Dărăbuş G., Oprescu I. Morariu S., Mederle Narcisa. Parazitologie şi boli parazitare. Ed., Mirton, Timişoara. 2006. $-836 \mathrm{p}$.

8. Dărabus Gh. Criptosporidioza. Tratat de Medicină Veterinară. Secțiunea a XII-a - Parazitologie Veterinară, Ed. Risoprint, Cluj-Napoca. 2014, vol. VI. - P. 281-301.

9. Dărabuș Gh. Strongilidoze digestive. Tratat de Medicină Veterinară. Secțiunea a XII-a - Parazitologie Veterinară, Ed. Risoprint, Cluj-Napoca. 2014, vol. VI. - P.648-723.

10. Didă I. Eimerioza bovinelor. Tratat de Medicină Veterinară. Secţiunea a XII-a - Parazitologie Veterinară, Ed. Risoprint, Cluj-Napoca. 2014, vol. VI. - P. 238-250.

11. Duchacek L., Lamka J. Dicrocoeliosis - the present state of knowledge with respect to wildlife species //Acta Vet. Brno. 2003, vol.72. - P. 613-626.

12. Dulceanu N. Cercetări privind schizonții giganți de Eimeria gilruthi din mucoasa abomasală la ovine. Revista Cercet. Agr. în Moldova. 1978, 2. - P.139-142.

13. Dulceanu N. Parazitozele animalelor de fermă. Ed. Ceres, București. 1986. - 492 p.

14. Erhan D. Tratat de parazitoze asociate ale animalelor domestic. Edit. Tipografia Centrală. 2020. $-1040 \mathrm{p}$.

15. Gorget Patricia Muriel. Toxocara canis et syndrome de larve migranss oculairevchez l'homme. Etude bibliographique. These por le doctorat veterinaire diplome d'etat, E.N.V. Toulouse, 1993.

16. Gregory G.G. Fecundity and proglottid release og Taenia ovis and T. hydatigena //Australian Veterinary Journal. 1976, 52 (6). - P. 277-279.

17. Hendrix C.M. Diagnostic veterinary parazitology. 2nd Eds. Mosby Inc. Ed., St. Louis. 1998 $321 \mathrm{p}$.

18. Jones G.W., Parker R.J., Parke C.R. C occidia associated with enteritis in grower pigs. Australian Veterinary Journal. 1985, 62(9). - P. 319.

19. Keegan J.D., Holland C.V. Contamination of the hair of owned dogs with the eggs of Toxocara 
spp //Veterinary Parasitology. 2010, 173. - P. 161-164.

20. Kesting V., Goleasch S., Zander C. Helgoland. Mursuntersuch. 1996. 50, № 4. - P. 477-496.

21. Lawson R., Gemmell M.A. Hydatidosis and Cysticercosis: the dinamics of transmission //Advances in Parasitology. 1983, vol. 22. - P. 261-308.

22. Marquardt W.H., Demaree R.S., Grieve R.B. Parasitology and vector biology. Second Edition. Harcourt Academic Press. 2000.

23. Mehlhorn H. (ed.), Armstrong P.M. et al. Encyclopedic reference of pa- rasitology. Springer Verlag. N.-Y. 2008. - 678 p.

24. Olteanu G., Negru D., Lungu V., Fromunda V., Stoican E, Georgescu L. ș.a. Prima Expediţie Parazitologică complexată în RPR și unele aspecte ale problemei ecologiei helminților. Com. Ses. șt. Institutului "Pasteur", 27-29.02.1964

25. Olteanu G., Panaitescu D., Gherman I. şi colab. Poliparazitismul la om, animale, plante şi mediu. Ed. Ceres. București, 2001. - 818 p.

26. Poulin R. Evolutionary Ecology of Parasites. From individuals to com- munities. London et ctr. 1998. - 212 p.

27. Price P.W. Evolutionary biology of parasites. Princeton, 1980. - 237 p.

28. Reinthaler F.F. Epidemiology of cryptosporidiosis in tropical coutriens. ж. Гигиены, Эпидемилогии, Микрбиологии и Эпидемиологии. 1989. Вып. 33. №4. Supliment. - С. 505518.

29. Rickard M.D., Arundel J.H. Chemotherapy of tapeworm infections in animals in Chemotherapy of gastrointestinal helminthes. Editors: Bossche, H.V., Thienpot, D., and Janssens, P.G., Springer-Verlag Ber- lin. 1985.

30. Rusu Ș., Chihai O., Anghel T. Măsuri de prevenire și combatere a echi- nococozei/hidatidozei. Chișinău. 2010. - 34 p.

31. Şuteu I. et. al. Anuar Inst. Agron. Cluj-Napoca. 1978. - P. 131-135.

32. Şuteu I., Cozma V. Parazitologie clinică veterinară. Cluj-Napoca, 2007, Vol. I. - 316 p.

33. Şuteu I., Cozma V. Parazitologie clinică veterinară. Cluj-Napoca, 2007, Vol. II. - 349 p.

34. Taylor M.A., Hunt K.R. Anthelmintic drug resistance in the UK. Veterinary Record. 1989. V.125(7), - P. 143-147.

35. Thompson R.C.A. Biology and systematics of Echinococcus in Echi- nococcus and hidatid disease. Editors: Thompson, R.C.A. și Lymbery A.J., Cabi Publishing. 1995.

36. Torgerson P.R., Heath D.D. Transmission dynamics options for Echi- nococcus granulosus. Parasitology. 2003. - P. 143-158.

37. Авдюхина Т. И., Константинова Т. Н., Прокошева М. Н. Современный взгляд на проблему гельминтозов у детей и эффективные пути ее решения. Лечащий врач. М., 2004, № 1, с. $14-18$.

38. Балашов Ю.С. Паразито-хозяинные отношения членистоногих с наземными позвоночными. Тр. ЗИН АН СССР. Л.: Наука, 1982. Т. 97. - 320 с.

39. Беклемишев В.Н. Паразитизм членистоногих на наземных позво- ночных. І. Пути его возникновения //Биоценолоические основы сравнительной паразитологии. М. 1951. - С. 261-289.

40. Беклемишев В.Н. Паразитизм членистоногих на наземных позво- ночных. II. Основные направления ео развития //Биоценолоиче- ские основы сравнительной паразитологии. M. 1954, с. 289-311.

41. Бигон М., Харпер Дж., Таунсенд К. Экология. Особи, популяции и сообщества. М. Мир. 
1989. T. 1. - 667 c.

42. Бигон М., Харпер Дж., Таунсенд К. Экология. Особи, популяции и сообщества. М. Мир. 1989, T. 2, 477 c.

43. Дмитриева Е.Л. Распространение возбудителя криптоспоридиоза в природных и синантропных биоценозах Центрально-Черноземной зоны: на примере Курской области. Автореф. кандидат биол. Наук. Курск. 2008, 22 с.

44. Догель В.А. Очередные задачи экологической паразитологии. Тр. Петергоф. биол. ин-та. 1935. Т. 15. - С. 31-48.

45. Дубровский Ю.А. Доказательства прирдной очаговости крипто- споридиоза //ж. Микробиология, эпидемиология и иммунобиология. 1997, 2, с. 71-73.

46. Кеннеди К. Экологическая паразитология. М.: Мир, 1978. - 232 с.

47. Комплексная программа интенсификации производства молока и мяса до 1990 года в Молдавской ССР, 1990.

48. Лубянецкий С.А. Ветеринарно-санитарная экспертиза мясопродуктов при саркоспоридиозе животных: Автореф. дис. д-ра вет. наук. Ульяновск,1956, 24 с.

49. Обухов В.Е. Методологический анализ развития экосистем. Теория развития и естествознания. М. 1989. - С. 131-141.

50. Павловский Е. Н. Организм как среда обитания. Природа. 1934. № 1, с. 80-91.

51. Павловский Е.Н. Учение о биоценозах в приложении к некоторым паразитологическим проблемам. Известия АН СССР. Отдел мате- мат. и естествен. наук. 1937. № 4. - С. 13851422.

52. Скрябин К.И. Симбиоз и паразитизм в природе. Петроград, 1923. - 276 с.

53. Скрябин К.И. Метод полных гельминтологических вскрытий позвоночных, включая человека. Издательство 1-го МГУ. М., 1928. - 45 с.

54. Филипченко А.А. Экологическая концепция паразитизма и само- стоятельность паразитологии как научной дисциплины //Уч. зап. ЛГУ. Сер. биол. 1937. Т. 13, вып. 4. - С. $1-14$. 